\title{
Hydrodynamic Modelling of Bidong Island Vicinity Waters
}

\author{
Nurul Rabitah Daud, Mohd Fadzil Mohd Akhir \\ Institute of Oceanography and Environment, Universiti Malaysia Terengganu, Terengganu, Malaysia \\ Email: rabitahnurul@gmail.com
}

Received 28 May 2015; accepted 26 July 2015; published 29 July 2015

Copyright (C) 2015 by authors and Scientific Research Publishing Inc.

This work is licensed under the Creative Commons Attribution International License (CC BY). http://creativecommons.org/licenses/by/4.0/

(c) (i) Open Access

\section{Abstract}

This paper explores the dynamic of meteorological forcing on current circulation pattern in the vicinity of Bidong using an unstructured flexible mesh hydrodynamic model. The forcings were wind, tides, temperature and salinity. The seasonal wind monsoon, mixed tides with dominant diurnal and tropical monsoon climate is characteristics of Bidong Island. We find that this area has different current circulation patterns in response to monsoon changes. It also experienced a small scale of island wake during NE monsoon. This island wake was generated by a strong northeasterly wind. We performed a series of numerical simulations based on three dominant factors in circulation, and evaluated the model using wind, tides and density. We investigated the wind-driven circulation and residual current. This study contributes to the debates on hydrodynamic of current circulation in vicinity of Bidong Island. Specifically, this study was conducted to understand the changes of currents by seasonal wind (NE monsoon and SW monsoon), temperature and salinity.

\section{Keywords}

Hydrodynamic, Current Circulation, Island, Modeling, Monsoon

\section{Introduction}

Terengganu coast located directly facing to South China Sea (SCS). Terengganu coastal water physical properties and dynamical movements are influenced by SCS condition. Terengganu coast with a maximum depth lesser than $100 \mathrm{~m}$, is a shallow shelf in the southern part of SCS. It is generally regarded to range from $4^{\circ} \mathrm{N}$ to $6^{\circ} \mathrm{N}$ and from $102.5^{\circ} \mathrm{E}$ to $104.5^{\circ} \mathrm{E}$ (see Figure 1), and it is a sloping cape along the coastline east coast Peninsula Malaysia. This region is important as it is believed to hold huge oil and gas reserves beneath its seafloor [1].

Terengganu coastal area is habited several islands such as Tenggol Island, Kapas Island, Bidong Island, Redang Island and Perhentian Island (see Figure 2). The islands are characterized by highly diverse ecosystems 


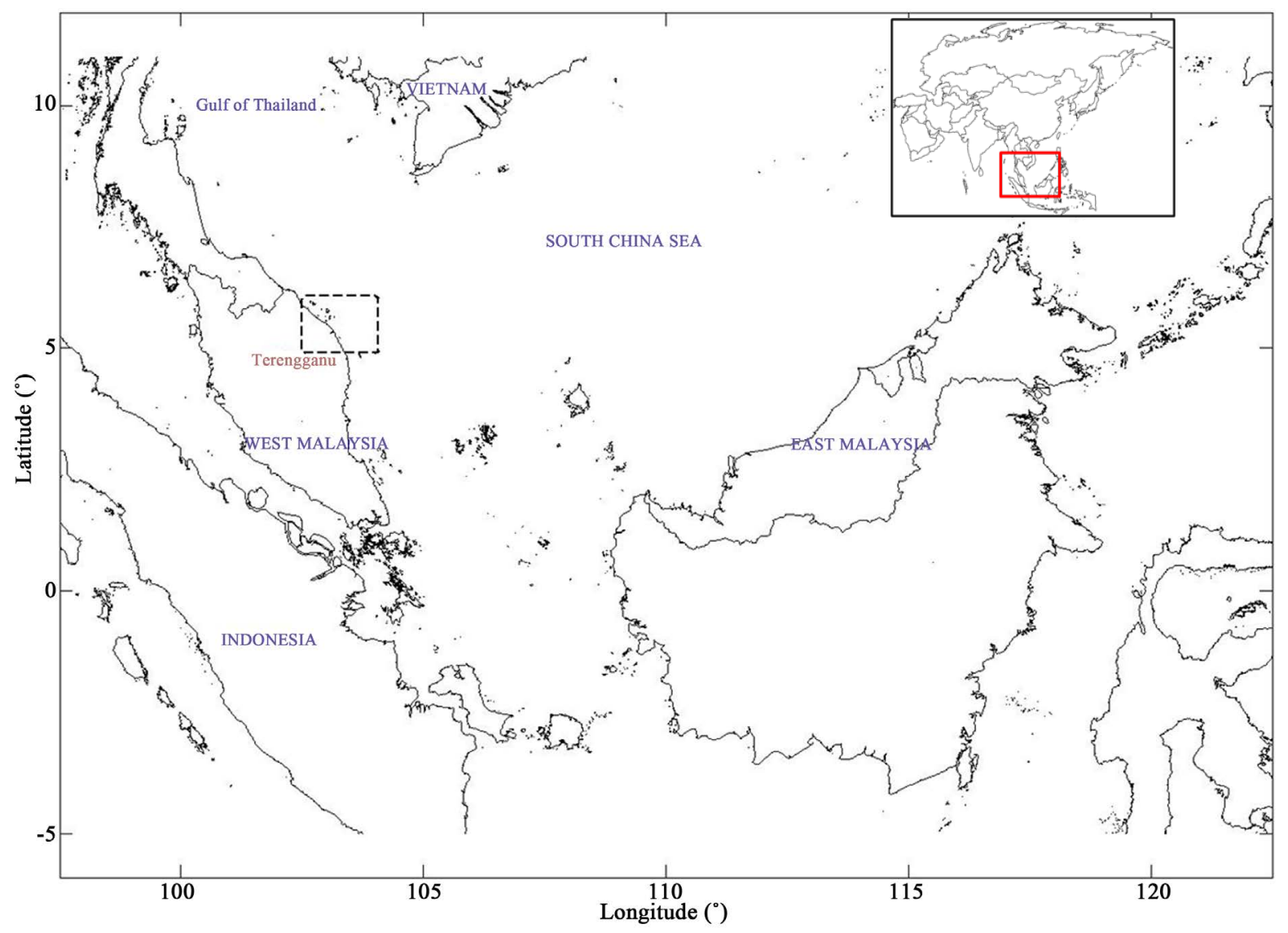

Figure 1. The focus area of this study (in box), Terengganu coastal area.

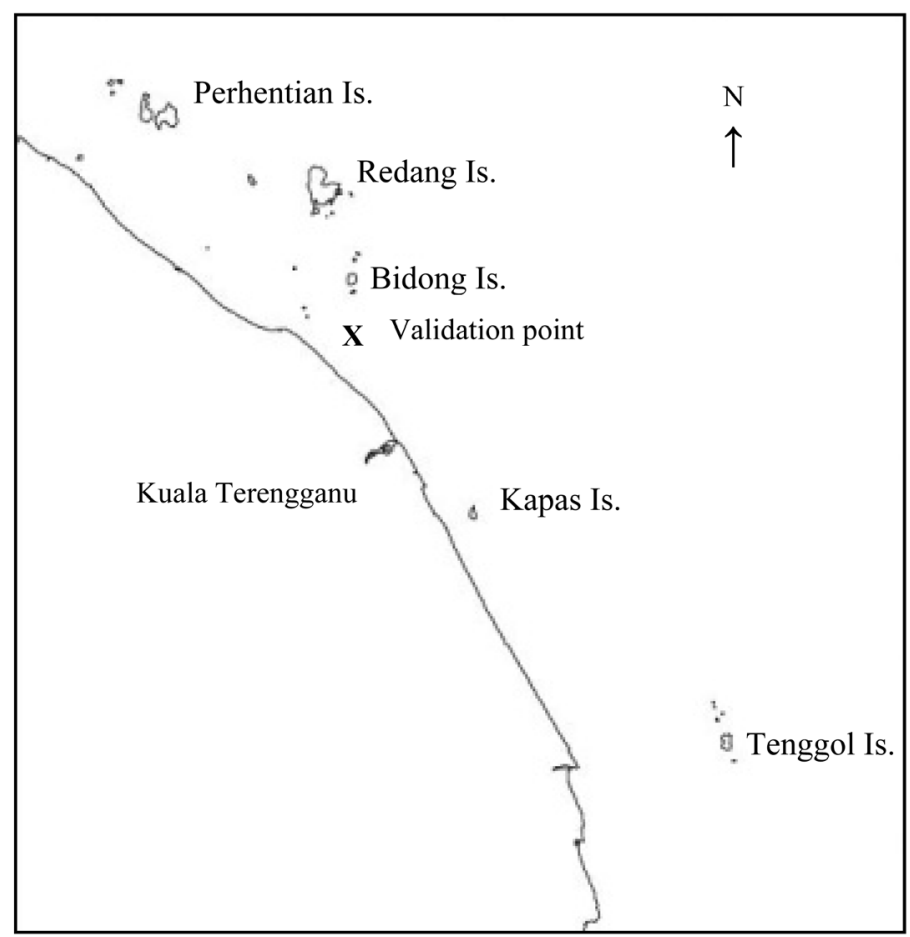

Figure 2. Islands in Terengganu waters and validation point (symbol; $\mathbf{X}$ ). 
and a great number of functions are performed over a relatively small area. For example around Bidong island, the productivity level around this island is quite high as there is present few of fish cages for mariculture and operating of fishing activity and squid jigging seasonally.

The Bidong Island is a small island located about $14 \mathrm{~km}$ from mainland. There are two islands close to it: Tengkorak Island and Karah Island and its surrounding water depth is less $30 \mathrm{~m}$ (see Figure 3). This island received influence from mainland in its current circulation. This island is also active with research activity especially for fish and coral diversity.

The water circulation develops an essential part of the dynamic processes in vicinity of island water and the tidal cycle could be part of this circulation. An attractive phenomenon with relate to water circulation around an island is the island wake. Depending on several dynamical factors, a current circulation around an island may generate a wake [2].

Many previous studies documented about the biological enrichment in vicinity island water compared to surrounding water [3]-[5]. Among these, some are particularly relevant to this study. Referring [6] investigated the island wake phenomena in waters around Tinggi Island, Johor based on the results of the ADCP measurements. They found out that that currents flow may produce a pair eddy of opposite direction and a return flow at the southern end of the island consequence of the estimated shallow water Reynolds number. They also found at bottom layer a depth about $15 \mathrm{~m}$ from seabed, the speed is greatly influenced by the bottom friction. However, the speed decrease in the upper layer is due to wind influence. At the surface, the opposite winds slowed down the current speed by almost $0.1 \mathrm{~m} / \mathrm{s}$.

Numerous studies can be found on numerical modelling of current circulation on central basin of South China Sea and less attention has been drawn on the Terengganu coast, Peninsular Malaysia. Thus, this area has been poorly investigated, especially considering its important geographical location, the significant roles of its physical process and the impact of seasonal monsoon to Terengganu coastline. In area of Southern South China Sea (SSCS), physical properties and dynamical movements are influenced by monsoon winds. Atmospheric global wind patterns play a tremendous role to influence the physical properties of ocean. In coastal water, such as east coast of Peninsular Malaysia, the water circulation is subjective by wind monsoon patterns [7]-[9].

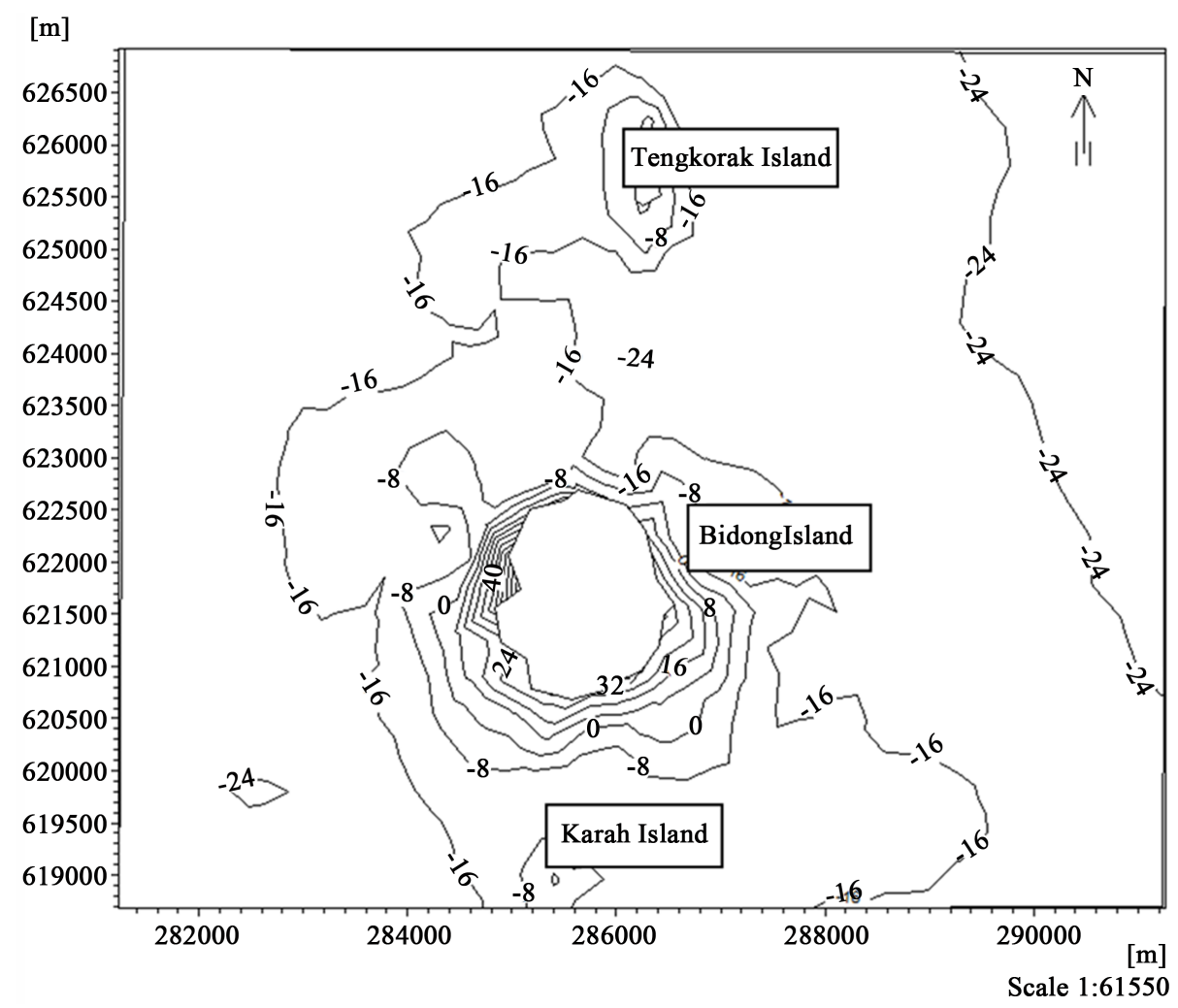

Figure 3. Bidong Island bathymetry. 
Currents of the SSCS are divided as wind driven currents generated due to wind stress while tidal currents due to the tidal effect. It is generally thought that the wind stress is the major driving force for SSCS. During November to March the SSCS is received NE monsoon which driven by a strong northeasterly wind and steer a strong southwesterly current at east coast Peninsular Malaysia. At the centre of SCS it has the circulation of shelf which during the SW monsoon, the circulation on the shelf is directed northward. During April to August the SW monsoon driven by southwesterly winds and generate a northward current at east coast Peninsular Malaysia [10].

In the present study, attempt has been made to see the circulation response of Terengganu coastal area by using wind stress data with different magnitude and direction. This will enable us to understand the sensitivity of wind stress forcing and current circulation response in the Terengganu waters. The model used in this work was Mike 21 Flow Model FM which was initially developed for hydrodynamic in regional simulation but now used for coastal simulation. Since the scope of modelling experiments are in coastal and island vicinity, we decided to provide the result in several parts: part I, wind-driven current in Bidong island waters and in part II, residual current in Bidong island vicinity. The main objective of part $\mathrm{I}$ is to determine the wind-driven current field in Bidong island waters during NE and SW monsoon seasons. Meanwhile, objective of part II is to examine the residual current in Bidong Island vicinity seasonally.

\section{Material and Methods}

\subsection{Model Specification and Numerical Schemes}

The three-dimensional MIKE 21 FM model developed by the Danish Hydraulic Institute will use to study the hydrodynamics of the region for 2D free-surface flows. MIKE 21 is applicable to the simulation of hydraulic and related to phenomena in lakes, estuaries, bays, coastal areas and seas. MIKE 21 Flow Model FM is a modelling system based on a flexible mesh approach. The flexible mesh is most suitable for irregular boundaries of the water body. The modelling tool has been developed for applications within oceanographic, coastal and estuaries environments.

The model specifications of this study are as follows: the model domain for the Bidong Island used unstructured mesh. The grid system for the model domain is composed of unstructured mesh had a resolution of $10 \mathrm{~km}$, with finer resolution of $2 \mathrm{~km}$ in Bidong Island vicinity. The model setting was run for 30 days with 10 days reserved for model spinning time Table 1.

Mike 21 Flow Model FM has been used in this study which is based on the numerical solution of the incompressible Reynolds averaged Navier-Stokes equations invoking the assumptions of Boussinesq and hydrostatic pressure. The spatial discretization of the primitive equation is performed using a cell-centered finite volume method [11].

Table 1. Hydrodynamic model setup.

\begin{tabular}{|c|c|c|}
\hline Name & Notation & Setting \\
\hline Wind drag multiple & $\mu$ & 1.3 \\
\hline Run length & - & $30 \mathrm{~d}$ \\
\hline Time step & $\Delta \mathrm{t}$ & $21,600 \mathrm{~s}$ \\
\hline Initial conditions & - & Still water condition at GEBCO one min grid \\
\hline Boundary conditions (open) & - & Tidal elevation (K1, O1, M2, S2) \\
\hline Boundary conditions (closed) & - & No normal flow \\
\hline Forcing ramp & - & $10 \mathrm{~d}$ \\
\hline Minimum bottom friction coefficient & $\mathrm{C}_{\mathrm{f}, \min }$ & 0.0025 \\
\hline Minimum wetted bathymetric depth & $\mathrm{h}_{\mathrm{o}}$ & $0.1 \mathrm{~m}$ \\
\hline Minimum wetting velocity & $\mathrm{V}_{\text {min }}$ & $0.01 \mathrm{~m} / \mathrm{s}$ \\
\hline Horizontal eddy viscosity & $\mathrm{V}_{\mathrm{T}}$ & $0.28 \mathrm{~m}^{2} / \mathrm{s}$ \\
\hline Bed resistance & $\mathrm{n}$ & $32 \mathrm{~m}^{1 / 3} / \mathrm{s}$ \\
\hline
\end{tabular}


This model used computational unstructured mesh as the domain. Specifications required generating the domain and meshing in this study involved; maximum element area: $0.0003^{2}$, smallest allowable angle: 26 , maximum number of nodes: 100,000, interpolation method: the linear method, size of bounding: $100 \%$ beyond convex hull.

Model was initialized with the six-hourly HYCOM (HYbrid Coordinate Ocean Model) data for temperature and salinity. The open lateral boundary condition has been used in the experiments. The north, east and south open boundaries of the model are governed by the Flather condition. It was very efficient in connection with outer model simulation area to local area [12]. Therefore, the instabilities which are often occurred when imposing stratified density at a water level boundary can be avoided. A Smagorinnsky-type horizontal diffusion was used with $0.28 \mathrm{~m}^{2} / \mathrm{s}$ Smagorinsky coefficient. This value was constant in domain. The Smagorinsky formulation proposed to express sub-grid scale transports by an effective eddy viscosity related to a characteristic length scale [12].

The first part of this study, eight set of experiments (Table 2) have been performed for sensitivity of surface wind stress in the Bidong Island waters. This experiments designed to achieve first objective of wind driven current in Bidong Island. Adopting the without wind influence, moderate and extreme situation on both wind direction and wind speed in model was tested. In the simulation the wind direction were from southwest $\left(225^{\circ}\right)$, from north east $\left(45^{\circ}\right)$ (both representing southwest monsoon and northeast monsoon accordingly). Wind speeds were $20 \mathrm{~m} / \mathrm{s}$ in extreme condition, $10 \mathrm{~m} / \mathrm{s}$ in moderate condition, $5 \mathrm{~m} / \mathrm{s}$ low current speed and without wind speed. Each simulation was conducted for 40 days period, the first 10 days were for achieving steady-state conditions.

The second part of this study, experimental analysis has been conducted based on three dominant factors in circulation. This experiment analysis conducted to achieve second objective of hydrodynamic in Bidong Island. The factors evaluated are wind, tides and density. The model runs (see Table 3) are undertaken including and excluding the three main forcing terms. Each case has been run in specified condition. The model's running cases are given in Table 3 .

Table 2. Parameters in sensitivity analysis.

\begin{tabular}{|c|c|c|}
\hline & Wind direction & Wind speed $(\mathrm{m} / \mathrm{s})$ \\
\hline Case 1 & NE & 20 \\
\hline Case 2 & $\mathrm{NE}$ & 10 \\
\hline Case 3 & $\mathrm{NE}$ & 5 \\
\hline Case 4 & $\mathrm{NE}$ & 0 \\
\hline Case 5 & SW & 5 \\
\hline Case 6 & SW & 10 \\
\hline Case 7 & SW & 20 \\
\hline Case 8 & SW & 0 \\
\hline
\end{tabular}

Table 3. Numerical experiments.

\begin{tabular}{cc}
\hline $\begin{array}{c}\text { Experiment } \\
\text { E1 }\end{array}$ & Barotropic tidal current simulation \\
E3 & Baroclinic current simulation in August, without tides or wind forcing \\
E4 & As in experiment E2, but with tidal effect \\
E5 & As in experiment E4, but with tidal effect \\
E6 & Baroclinic current simulation in December, with wind forcing \\
E7 & As in experiment E6, but with tidal effect \\
\hline
\end{tabular}


In order to understand the phenomena of island wake, it is necessary to understand the theory of the phenomena. The theory of the wake behind an island has an extended history in fluid dynamics. Laboratory experiments [13] suggest that a two-dimensional flaw passing around an obstacle can be parameterized by the Reynolds number.

From the theoretical point of view, the appearance of an island on the flow field depends on the comparative of the inertial and frictional forces. If frictional dominates, the particles will be hauled along the island's coast. If the inertial force dominates the particles will be flung off from their paths and the flow will separate from the island. The ratio between inertial force and fractional force is given by Reynold number and for shallow water it is given as [6] [14]:

$$
\operatorname{Re}^{s}=\frac{u H^{2}}{A_{v} L}
$$

where $u$ is the background velocity, $\mathrm{L}$ is the width of the island, $\mathrm{H}$ is the water depth and $\mathrm{A}_{v}$ is the vertical eddy viscosity. Value for $A_{v}$ are variable between $10^{-5}$ to $10^{-1} \mathrm{~m}^{2} \cdot \mathrm{s}^{-1}$. For small $\mathrm{A}$, value of $10^{-5} \mathrm{~m}^{2} \cdot \mathrm{s}^{-1}$, the Reynolds number is slightly large, approximately 300 . With this large Reynolds number, the flow would be creating wake with wave turbulences and Karma vortices.

\subsection{Field Measurement and Datasets for Model Calibration and Validation}

An intensive field work had been carried out to validate the numerical model for four months. Model calibration was a step as fine tuning of parameters until the numerical model results and the field measurements within an acceptable tolerance by modifying the boundary conditions and improving the hydro meteorological forcing input [15]. According to [16] model calibration is an essential step of validation process to give an indication of the model's sensitivity and confidence that the results it produced were consistent with measurements.

There were two parameters adjusted during calibration, which were eddy viscosity and roughness bed resistance. There were also two calibrations done in this study, first using default values recommended by model developer. The value tested in model $32 \mathrm{~m}^{1 / 3} \mathrm{sec}^{-1}$ for bed resistance and 0.25 for the eddy viscosity. While, second using values suggested by researchers. The suggested values were $25.4 \mathrm{~m}^{1 / 3} \mathrm{sec}^{-1}$ for bed resistance [17] and 0.20 for eddy viscosity [18]. This value recommended based on geographical setting and boundary condition in domain area. As the study focusing on hydrodynamic on island circulation therefore, surface heat fluxes able to ignore as this factor largely influence on mixing and stratification of water column and also regional scale of study area [19] [20].

This study used surface elevation in model calibration because the effect of the roughness changes on the water surface elevations. This step was taken because the water level reflects on horizontal movement. This variables was adequate to calibrate the model and indicate the model's sensitivity in this study.

Afterward, the simulation output was compared with field measurement data, the bias of model and root mean square error (RMSE) were calculated. In order to have an estimate of the accuracy of the model result, the bias of the model was calculated. This is a systematic effect and gives an indication of the extent to which the model result is out of the measurement. While, the RMSE is a frequently used measure of the difference between values predicted by a model and the values actually observed from the environment that is being modelled [21] [22].

Furthermore, this study adopt the mathematical model validation in order to define the process of determining the model is an accurate representation of the real ocean from the perspective of the intended model applications. It is accomplished through the comparison of predictions from a model to experimental results. By referring to [16] used the zonal $(u)$ and meridional $(v)$ components of the currents derived from the measured elevation for the validation of model result. This study used current speed value for model validation.

\section{Result and Discussion}

\subsection{Model Validation}

The results of the models were validated with the 4-months Acoustic Wave and Current Profiler (AWAC) current speed data recorded near shore at Terengganu coastal waters (see Figure 2). The AWAC current speed measurements were available in six hourly interval covering a period of July-October 2011. 
The computed statistics for the entire data set including the bias and root mean square error (RMSE) were displayed in Figure 4. Generally, based on the scatter plots, the model performed reasonably well in simulating the current speed, with a bias of $0.06 \mathrm{~m} / \mathrm{s}$.

At certain time, the model underestimated the current speed. In this case, higher resolution of wind forcing was required to stimulate current speed in this area. Moreover, the current speed could be influenced by strong wind forcing, especially during monsoon season [23]. Although, accurate winds are critical in simulating coastal ocean circulation and dynamics [24] in this case, the ECMWF wind data is the best resolution reanalysis data available and many previous researchers used in model simulation as input data [25]-[27].

\subsection{Wind-Driven Current in Bidong Island Waters}

Flow fields at surface layer during NE monsoon and SW monsoon in different numerical experiment wind speed were shown in Figure 5 and Figure 6 respectively. Based on Figure 5(a), looking closely at Case 1, it can be seen that the current flow drifted strongly in southward direction. While in Case 2 in Figure 5(b) there was a clear strong current flowing between islands at the north part of Bidong Island. However this strong current reduced in Case 3 and Case 4. It is discovered that wind speed had capability to control current direction and current speed in the vicinity of this island.

On the other hand, based on Figure 6, a strong current between Bidong and Tengkorak Island was clearly seen in Case 7 and Case 5 but in different current magnitude. In Case 7 (see Figure 6(a)) a strong northeastward current flow between Tengkorak and Bidong island area was observed. While in Case 6 (see Figure 6(b)) current direction changed to northward and weaker current flow was observed in area between Tengkorak Island and Bidong Island.

Based on the simulation of experiments, statistical value was extracted to explore the relative significant of choice of parameters affecting the currents circulation result. The statistical current speed analysis consisted of maximum value, minimum value, mean and standard deviation. The values of all statistical analysis were shown in the Table 4. Based on Table 4 the maximum current during NE monsoon recorded was $0.44 \mathrm{~m} / \mathrm{s}$, while 0.11 $\mathrm{m} / \mathrm{s}$ in SW monsoon. However, from the mean value, during SW monsoon, it had higher current speed compare during December period was recorded. The mean values shows Case 8 has highest current speed and lowest in Case 3. This indicates in December strong northeasterly wind drives strong current around this island and weaken southwesterly wind during August reduces the current speed.

Other than difference in month, monsoon season and different wind direction also give large impact to current speed. During NE monsoon, it has large different range of maximum and minimum current speed. Meanwhile, during SW monsoon it had small different in current speed. This might be a sign of monsoon characteristic as NE monsoon has strong current but not during the entire period while SW monsoon has a consistent strength of

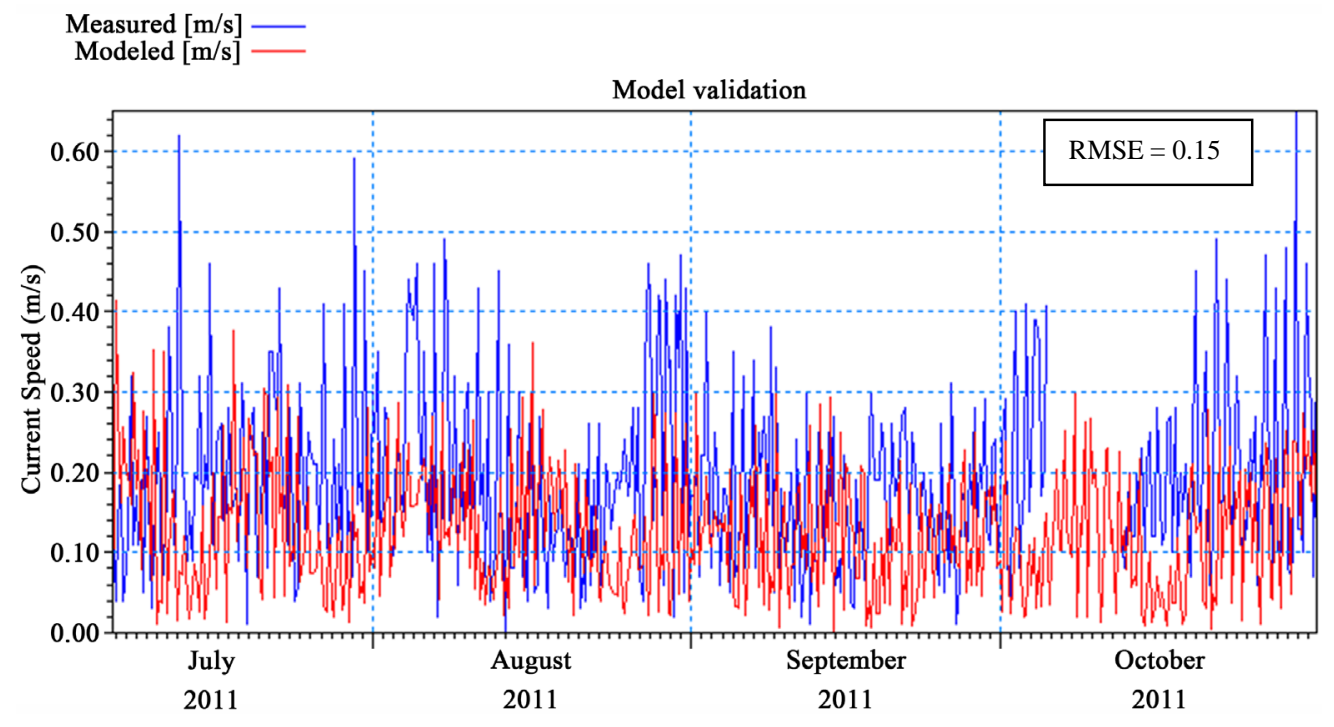

Figure 4. Comparison between modeled and measured (AWAC) current speed during period July-October 2011. 
$[\mathrm{m}]$

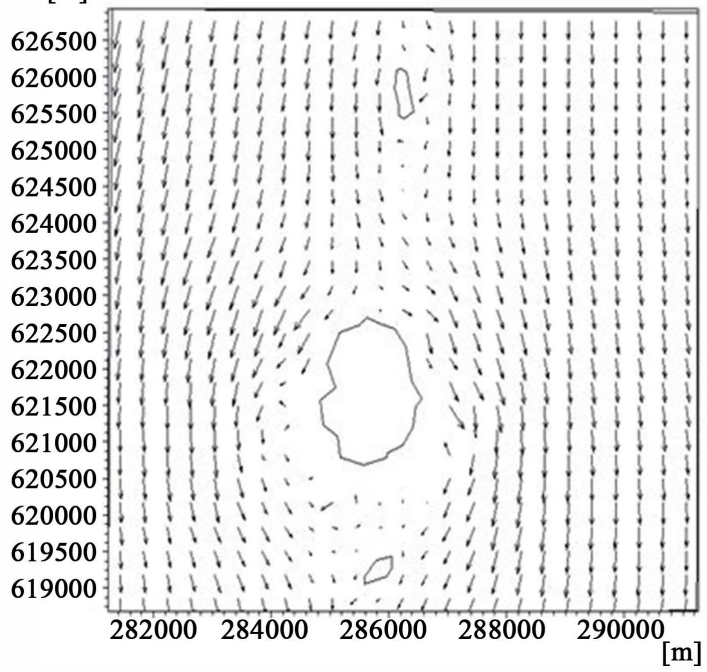

(a)

$$
\text { [m] }
$$

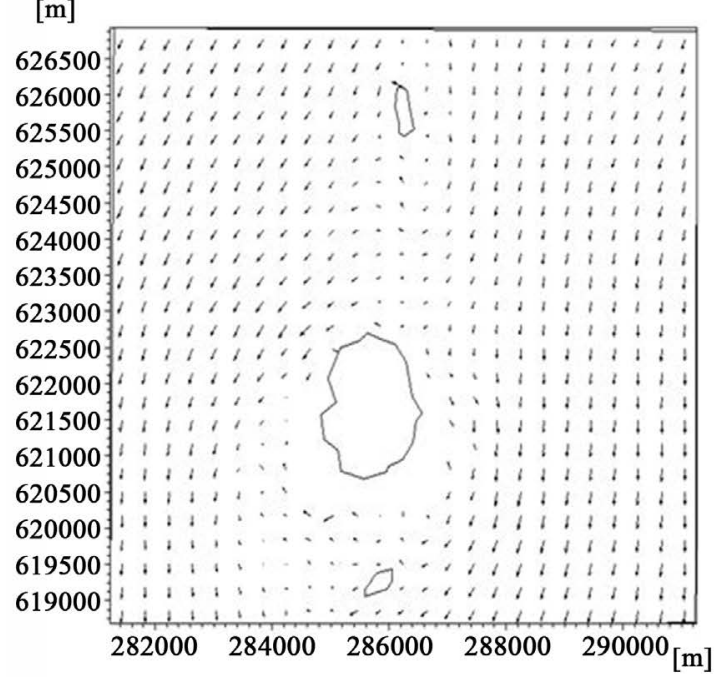

(c)

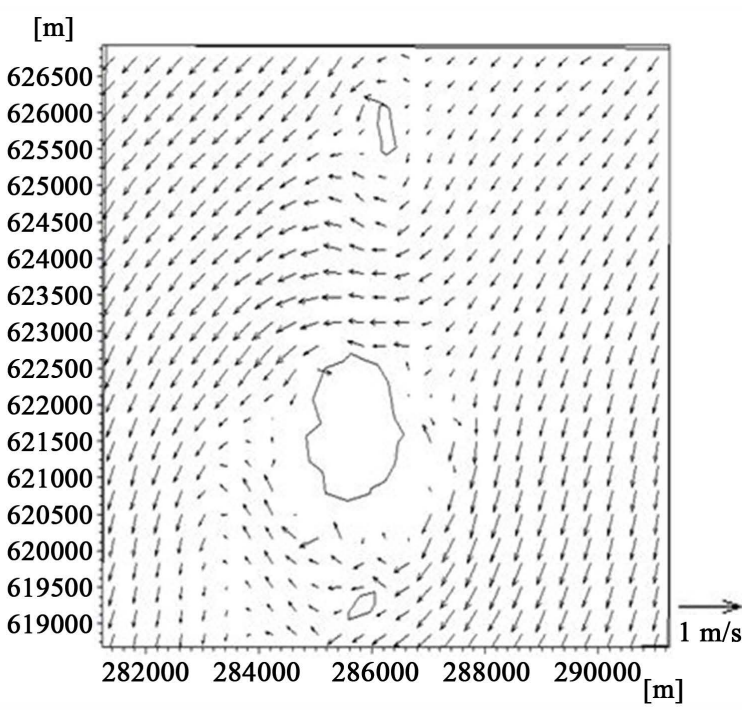

(b)

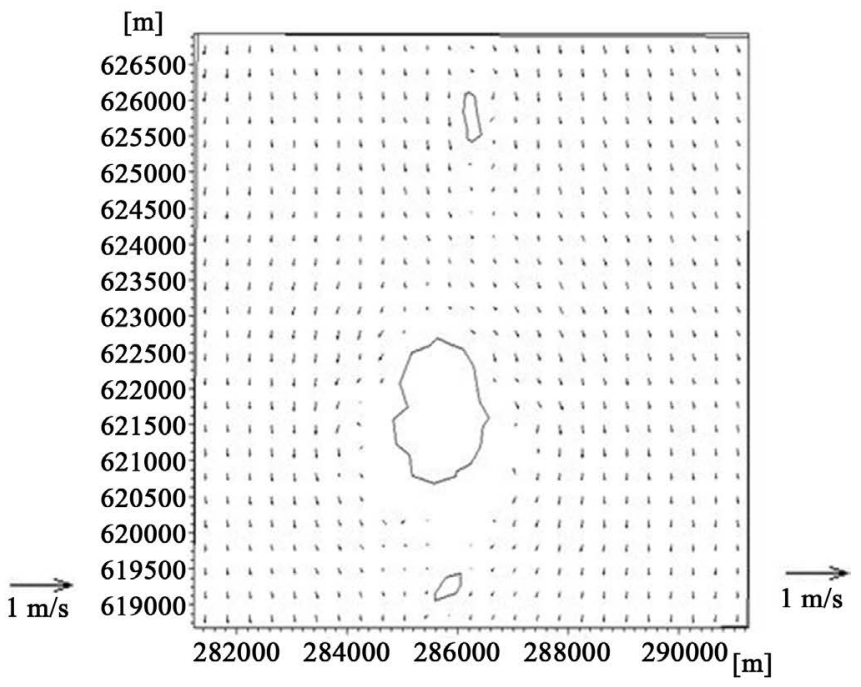

(d)

Figure 5. Current flow in Bidong Island waters in December (a) Case 1 with $20 \mathrm{~m} / \mathrm{s}$ wind speed (b) Case 2 with $10 \mathrm{~m} / \mathrm{s}$ wind speed (c) Case 3 with $5 \mathrm{~m} / \mathrm{s}$ wind speed (d) Case 4 no wind input.

Table 4. Statistical analysis from wind sensitivity model.

\begin{tabular}{cccc}
\hline Case & Max. value & Min. value & Mean \\
Case 1 & 0.442 & -1.142 & 0.001 \\
Case 2 & 0.438 & -1.136 & -1.136 \\
Case 3 & 0.338 & -1.136 & 0.001 \\
Case 4 & 0.338 & -0.795 & 0.001 \\
Case 5 & 0.195 & -0.795 & 0.005 \\
Case 6 & 0.196 & -0.804 & 0.005 \\
Case 7 & 0.105 & -0.795 & 0.004 \\
Case 8 & 0.195 & 0.005
\end{tabular}




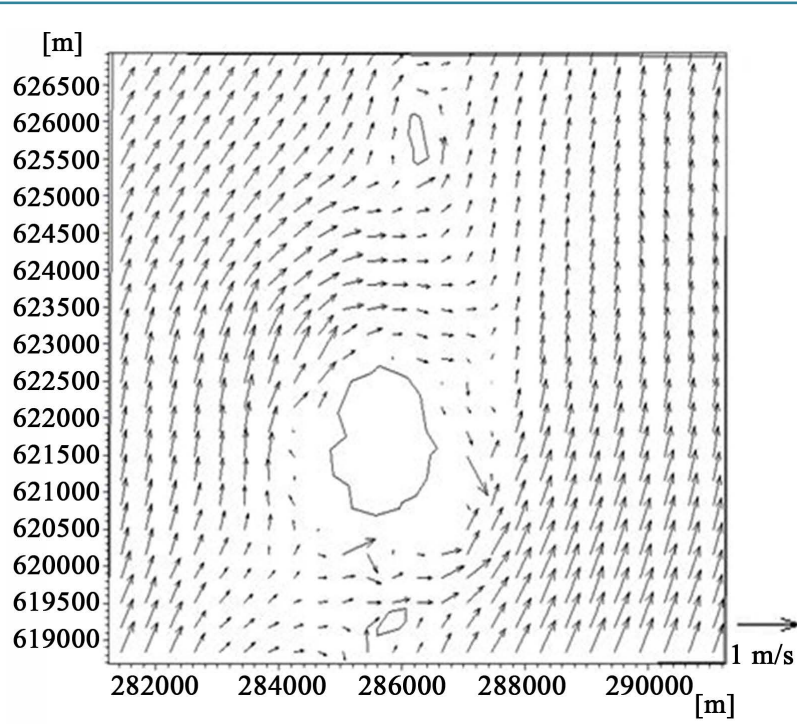

(a)

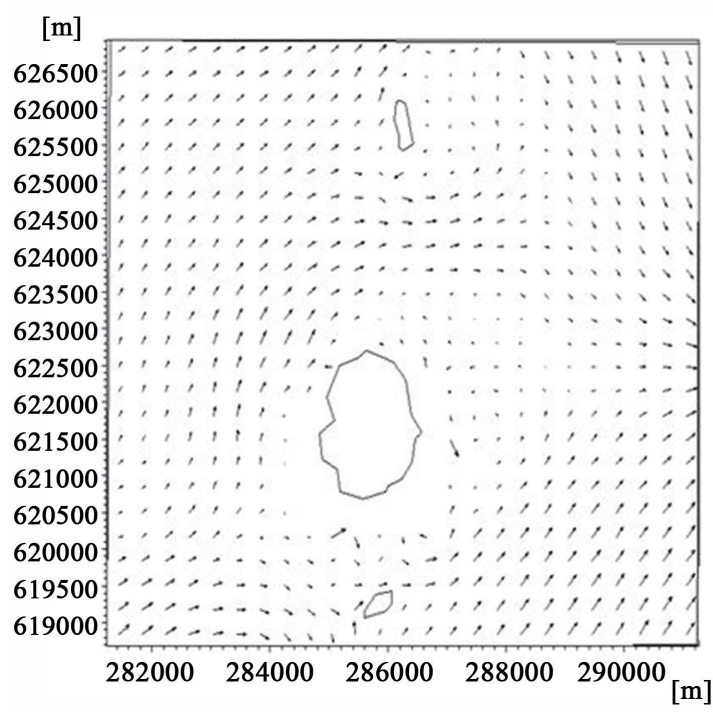

(c)

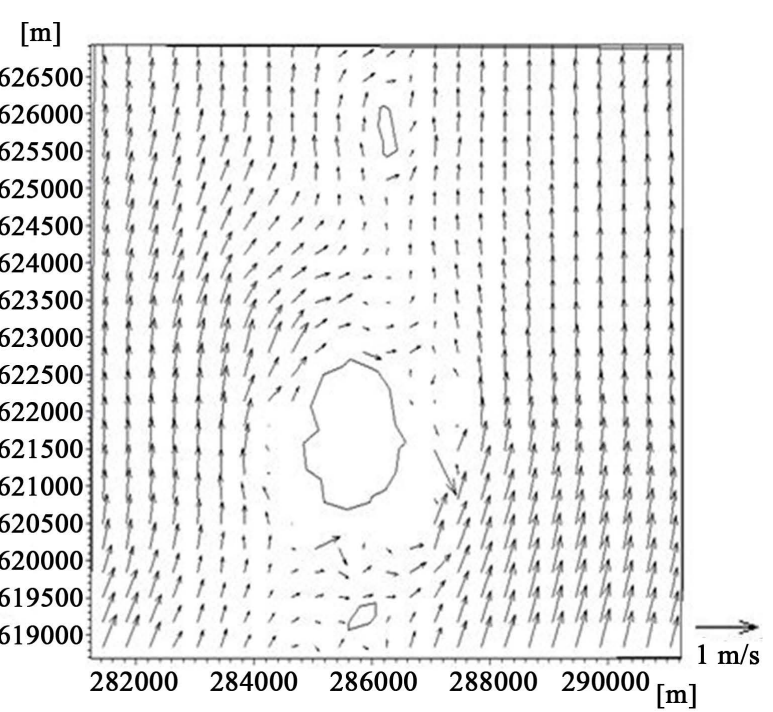

(b)

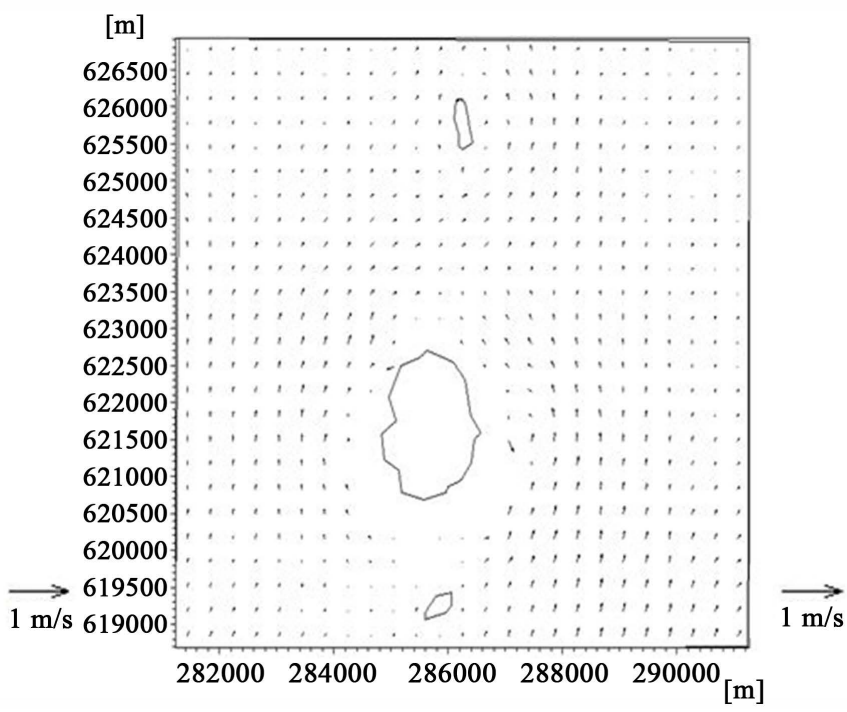

(d)

Figure 6. Current flow in Bidong Island waters in August (a) Case 7 with $20 \mathrm{~m} / \mathrm{s}$ wind speed (b) Case 6 with $10 \mathrm{~m} / \mathrm{s}$ wind speed (c) Case 5 with $5 \mathrm{~m} / \mathrm{s}$ wind speed (d) Case 8 with $0 \mathrm{~m} / \mathrm{s}$ wind speed.

current flow throughout the period.

Results from this part suggested that wind gave large impact to current speed and direction within the island vicinity. From previous study, in many cases; [23] [28] [29] current direction flow according to direction of wind and current speed strengthen by wind speed. Throughout the discussion in previous studies, it suggested a monsoon characteristic in SW monsoon had a consistent current strength as compared to NE monsoon. After knowing the influence of wind into current circulation, it was necessary to have a view on seasonal currents circulation. As reviewed from previous study, dynamic of current circulation in this area was mostly influenced by monsoon wind.

\subsection{Monsoon Seasonal Current Circulation}

For the duration of December, in Figure 7 and March, in Figure 8, circulation was almost in the same direction, presumably dominated by northeast monsoon. As the monsoon season period begins November until March [30]. In December it was peak of NE monsoon season and March was almost the end NE monsoon season. In the 


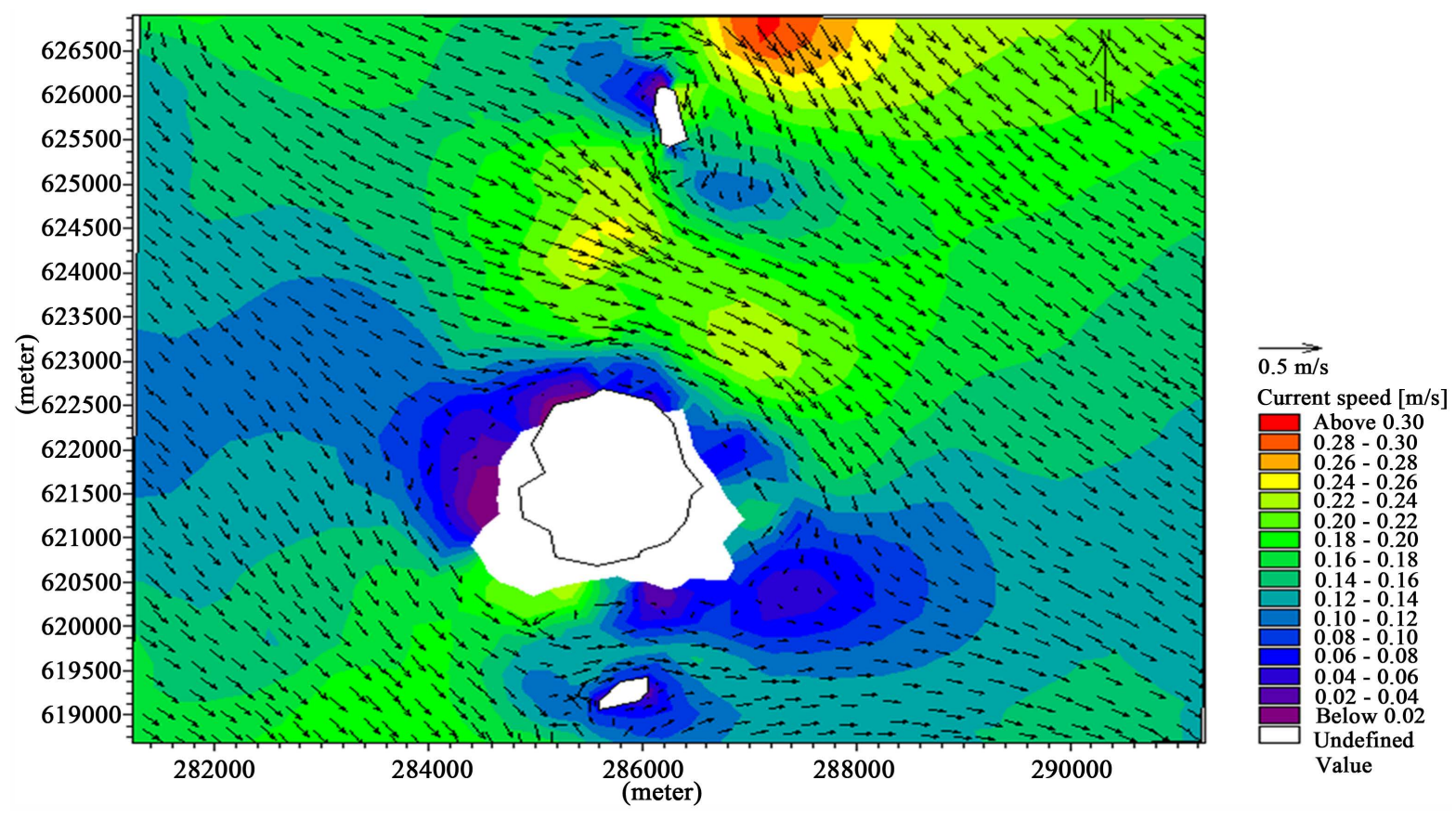

Figure 7. Current circulation in the vicinity of Bidong Island during December.

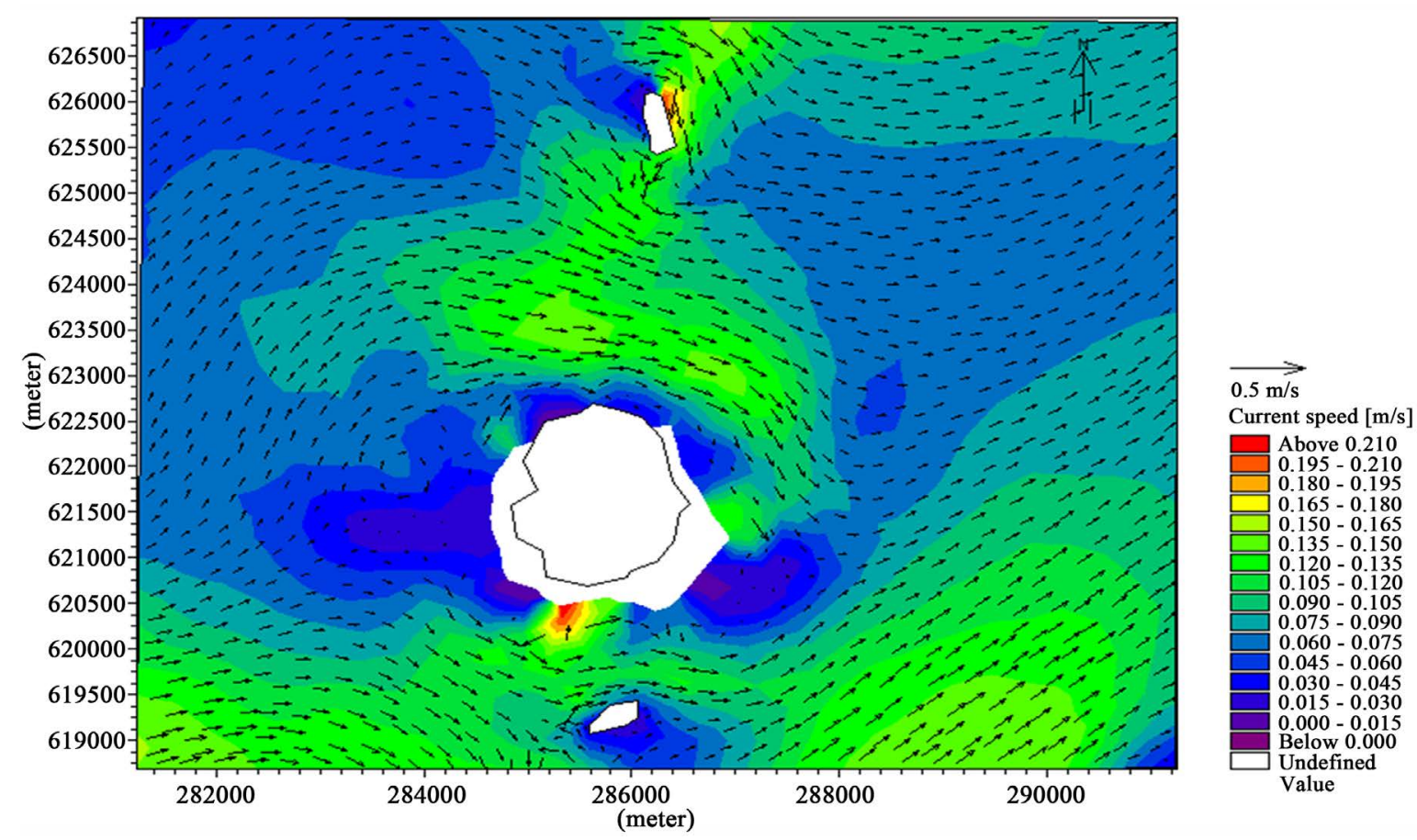

Figure 8. Same as Figure 7 but for March.

northern side of Bidong Island, strong channel of current flowed eastward. Similar current was observed in the south except the speed was slightly lower during December.

In Figure 7, maximum current speed was $0.32 \mathrm{~m} / \mathrm{s}$ which observed at eastern part of Bidong Island. The current moved in southward direction around the island specifically at western and eastern part of island. The average current speed around the island was in range $0.08-0.10 \mathrm{~m} / \mathrm{s}$.

While, in Figure 8 the current flowed in eastward direction with slight intensity northeast ward direction. The 
maximum current speed was $0.225 \mathrm{~m} / \mathrm{s}$ specifically at southern part of island and also at northern part of island has high current speed range $0.135-0.150 \mathrm{~m} / \mathrm{s}$ compared to other area around the island.

By using field data of December 2011 obtained from AWAC, a time series graph for current speed and direction was plotted in Figure 9. From this figure, it was discovered that a series of southeastward current occurred at early season. The highest current speed recorded was $0.62 \mathrm{~m} / \mathrm{s}$. The average current speed for this measured data set was $0.22 \mathrm{~m} / \mathrm{s}$.

Comparing with simulated result, the model has lower current speed compared to field measurement data. Maximum current speed from modelled was $0.23 \mathrm{~m} / \mathrm{s}$ however in measured data recorded maximum current speed $0.62 \mathrm{~m} / \mathrm{s}$ which the difference about $0.39 \mathrm{~m} / \mathrm{s}$. It is suggested that, there are other influence factors from the field did not well represent in simulation, namely, wind gust which blows at strong speed in certain time throughout the season.

During April, in Figure 10 and August, in Figure 11, circulation was in the different directions, presumably dominated by southwest monsoon. In the northern side Bidong Island, strong channel of current was seen flowing northward. On the contrary current was observed at the south part, which was slightly lower during August.

In Figure 10, maximum current speed was $0.20 \mathrm{~m} / \mathrm{s}$ which observed east off Bidong Island. The current moved in northward direction around the island specifically at western and eastern part of island. The average current speed around the island was in range $0.075-0.090 \mathrm{~m} / \mathrm{s}$. While, in Figure 11 the current also flowed in northward direction with slight intensity northeastward direction. The maximum current speed was $0.175 \mathrm{~m} / \mathrm{s}$ specifically at northern part of island and also at eastern part of island has high current speed range 0.120 - 0.135 $\mathrm{m} / \mathrm{s}$ compared to other area around the island.

Field observation of current speed and direction during August was shown in Figure 12. The highest speed recorded was $0.64 \mathrm{~m} / \mathrm{s}$ on $4^{\text {th }}$ August. The average current speed was $0.17 \mathrm{~m} / \mathrm{s}$. The frequency of maximum speed lay in early month and few days before the end of each month. This was suggested due to the end of SW monsoon season.

Comparing with simulated result, the model has lower current speed compared to field measurement data. Maximum current speed from modelled was $0.20 \mathrm{~m} / \mathrm{s}$ however in measured data recorded maximum current

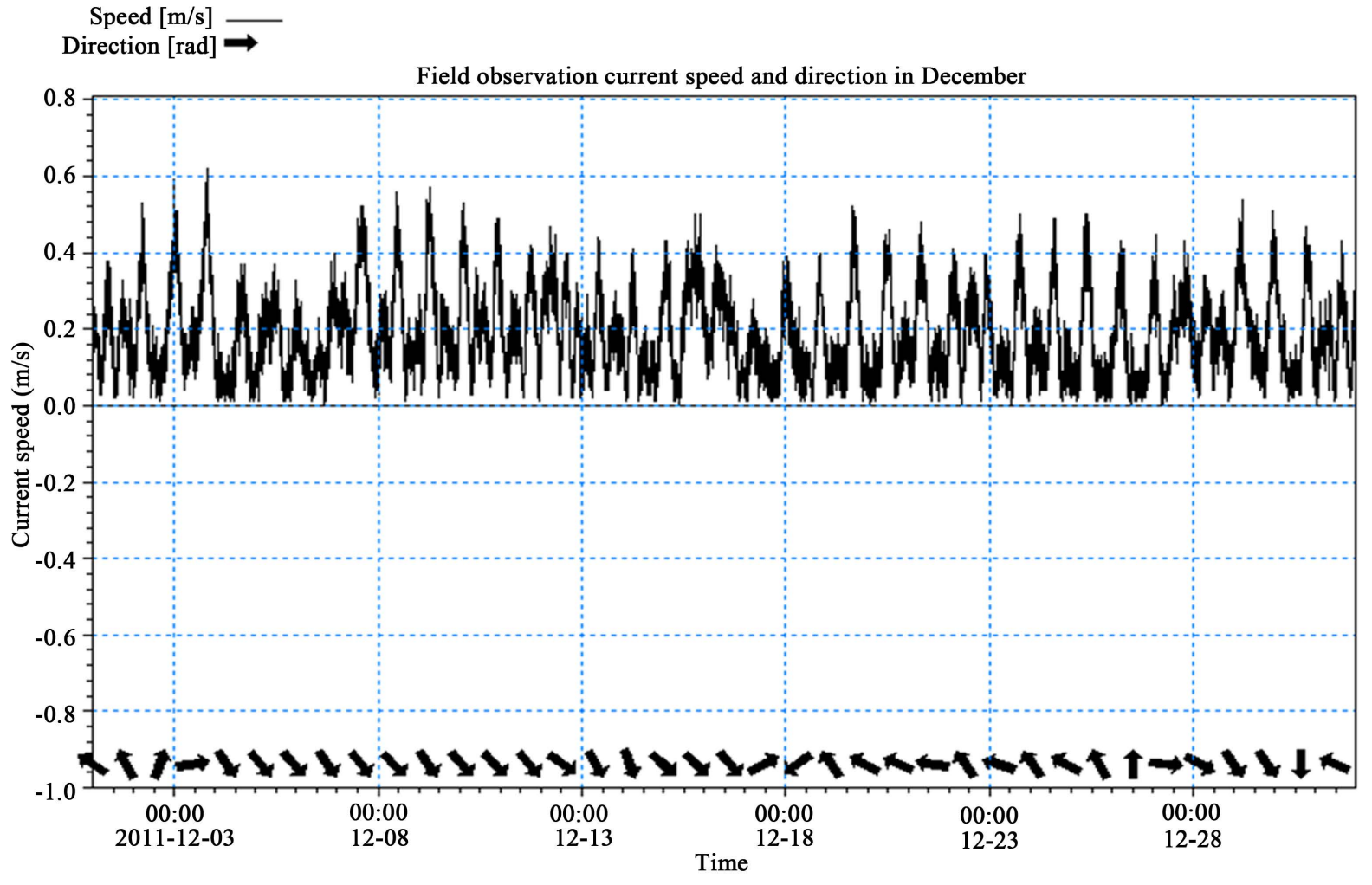

Figure 9. Field observation current speed and direction in December. 


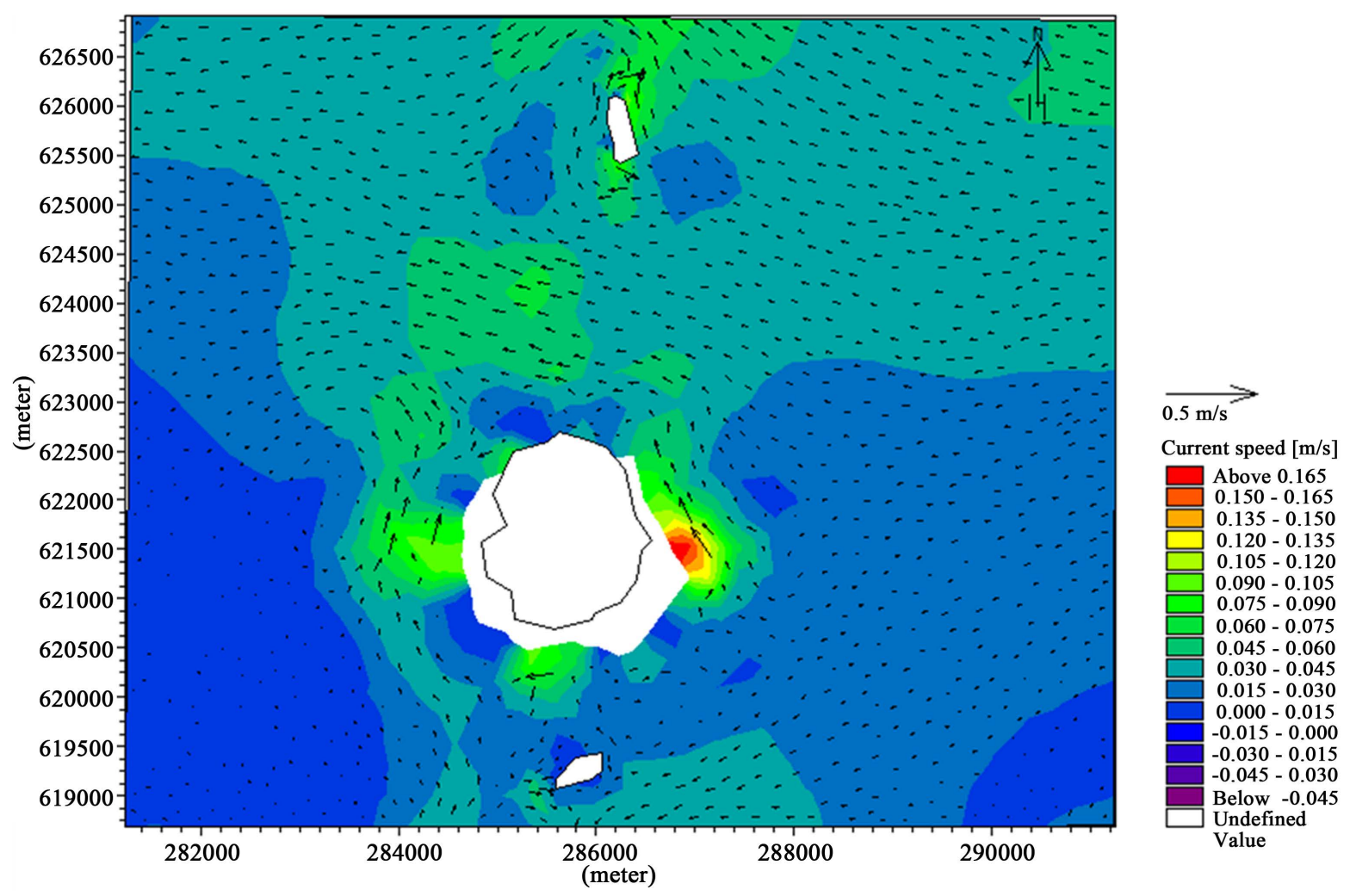

Figure 10. Same as Figure 7 but for April.

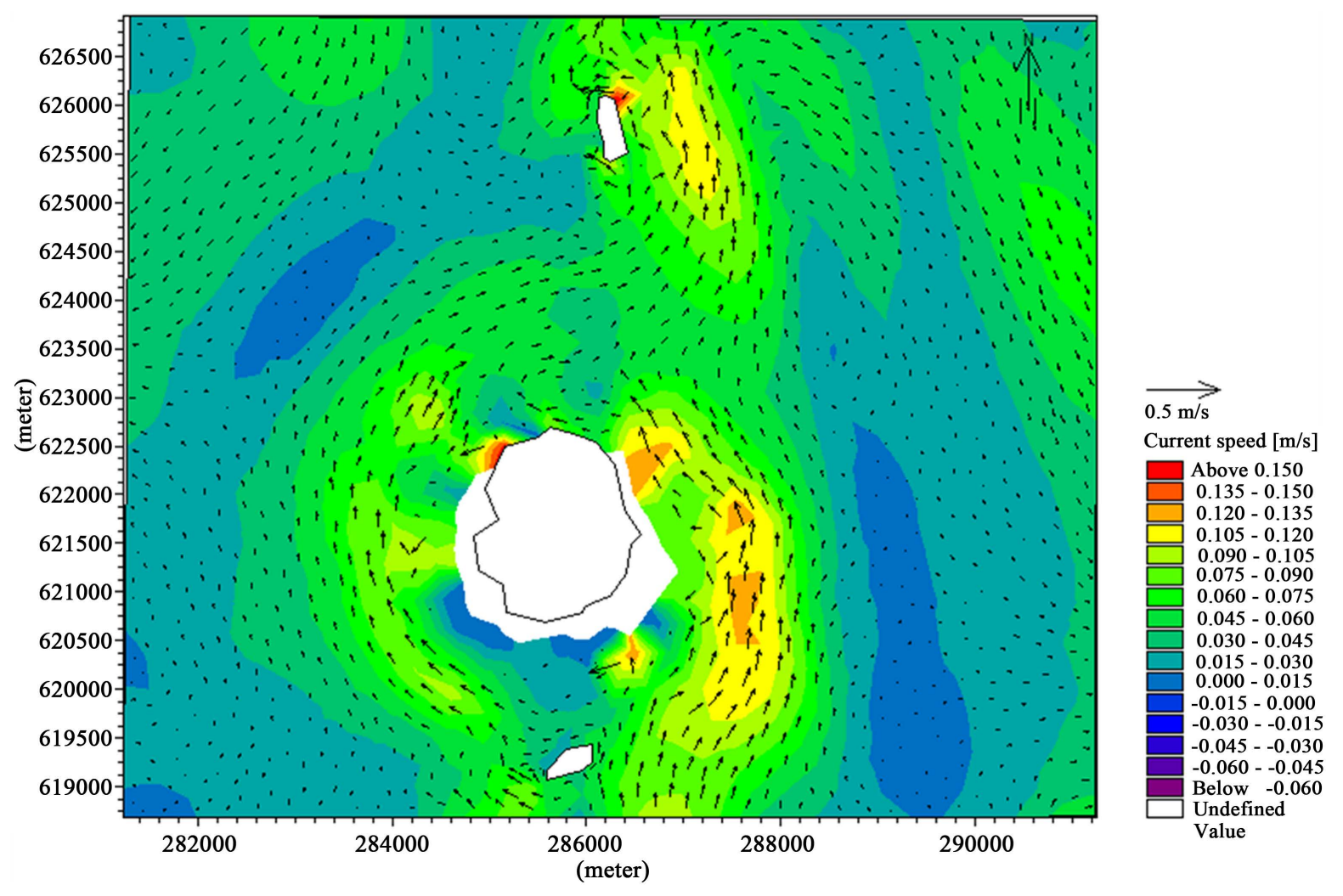

Figure 11. Same as Figure 7 but for August. 
Speed $[\mathrm{m} / \mathrm{s}]$

Direction [rad]

Field observation current speed and direction in August

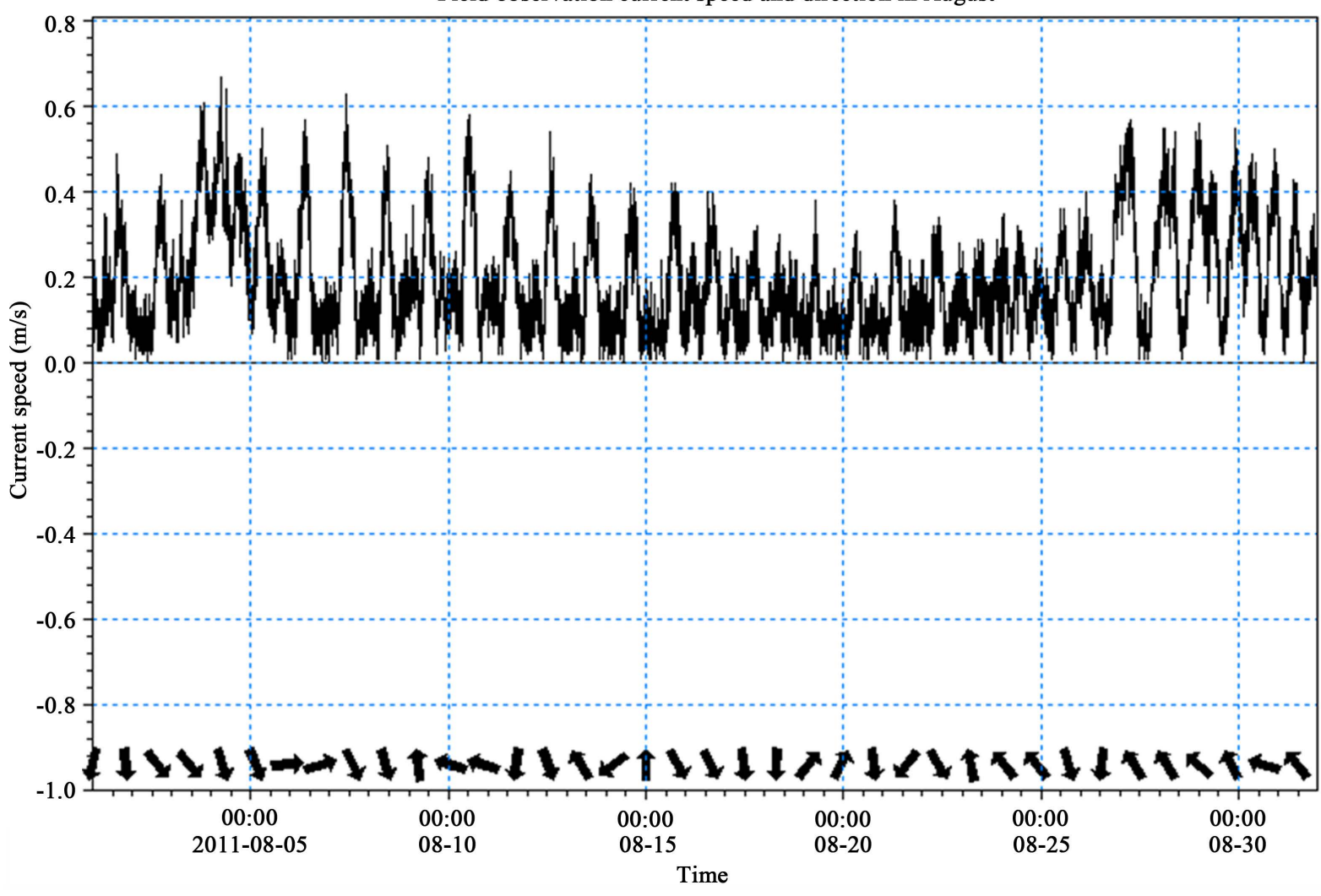

Figure 12. Field observation current speed and direction in August.

speed $0.64 \mathrm{~m} / \mathrm{s}$ which the difference about $0.4 \mathrm{~m} / \mathrm{s}$. It is suggested that, there are other influence factors from the field did not well represent in simulation, namely, wind gust and wave reflection.

\subsection{Residual Current Circulation}

Based on the E1 observation (see Figure 13), the current flowed in barotropic condition. The current was observed stronger around the island especially in the area facing open sea. At the most northern part the boundary effect took place and this might be an effect from the reflection from Redang Island.

The maximum current speed was $0.15 \mathrm{~m} / \mathrm{s}$ and minimum current speed was $0.04 \mathrm{~m} / \mathrm{s}$. This was considered high value in term of numbers because this model resolution was high and more detail as compared to Terengganu coast model.

There was no large difference between E1 and the model E2 which was processed in barotropic condition. An increasing of high current speed in the area because of the additional forcing which was density factor, which was also taken into account in this model.

In E3 which Figure 14, the tidal has influenced model. Therefore, the current speed gave greater value. The maximum current speed was $0.15 \mathrm{~m} / \mathrm{s}$ and minimum current speed was $0.05 \mathrm{~m} / \mathrm{s}$.

Based on experiment E4, there were four areas spotted as sheltered areas in the northern part of Bidong Island. While, there were three areas spotted in the southern part of island. This was due to bay in the island and reflection from nearer small islands around the Bidong Island. The maximum current speed in this E4 was $0.16 \mathrm{~m} / \mathrm{s}$ and minimum current speed was $0.04 \mathrm{~m} / \mathrm{s}$.

In E5 (see Figure 15), comparing the zone facing the open sea and the zone facing mainland, the zone facing open sea was showing higher current speed. The northern part of Bidong Island had a narrow strait connecting these two zones. As it was shown in Figure 15 the northern part of Bidong Island was having higher current 


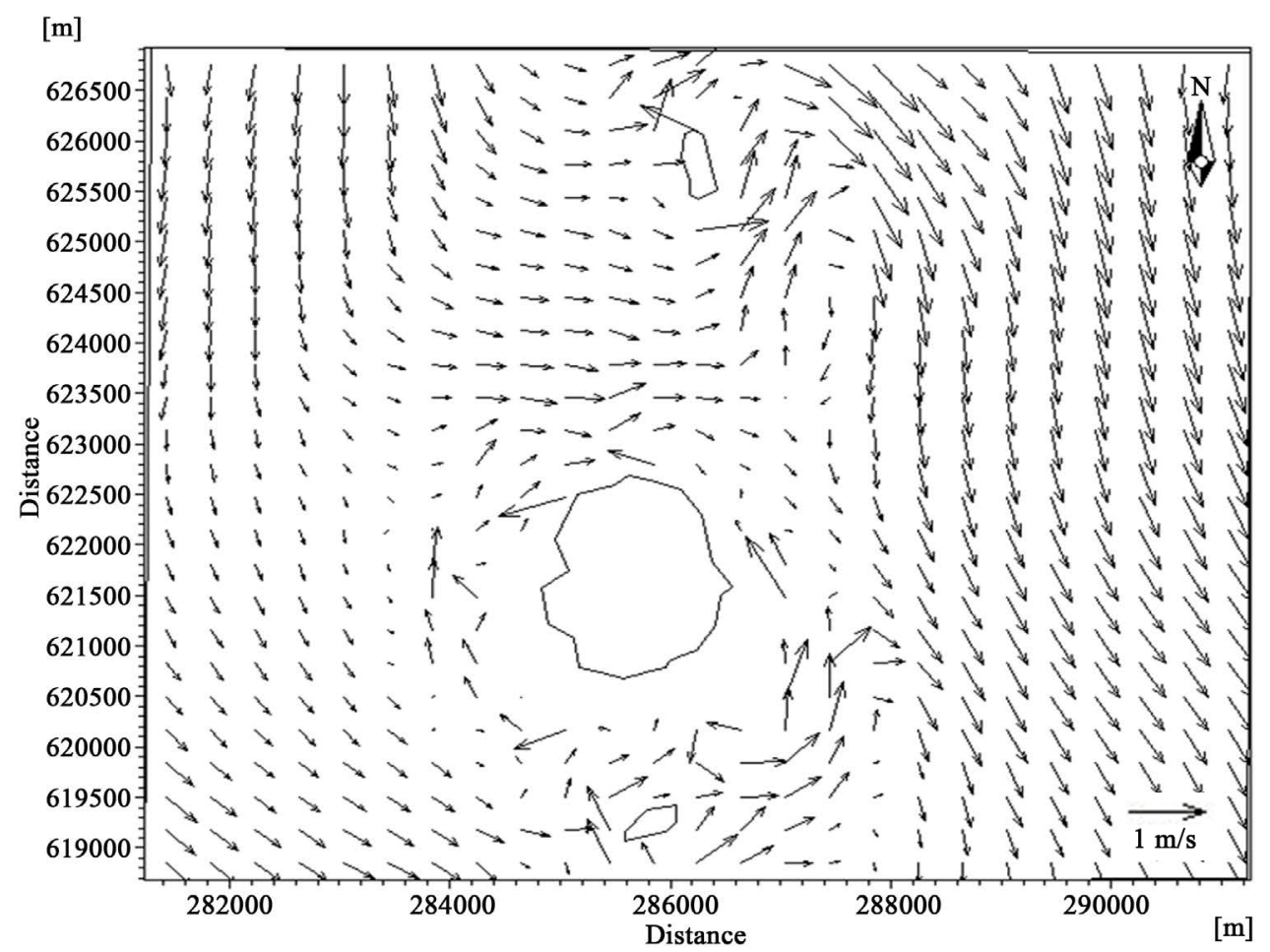

Figure 13. Ocean currents in the vicinity of Bidong Island in the case of Experiment 1.

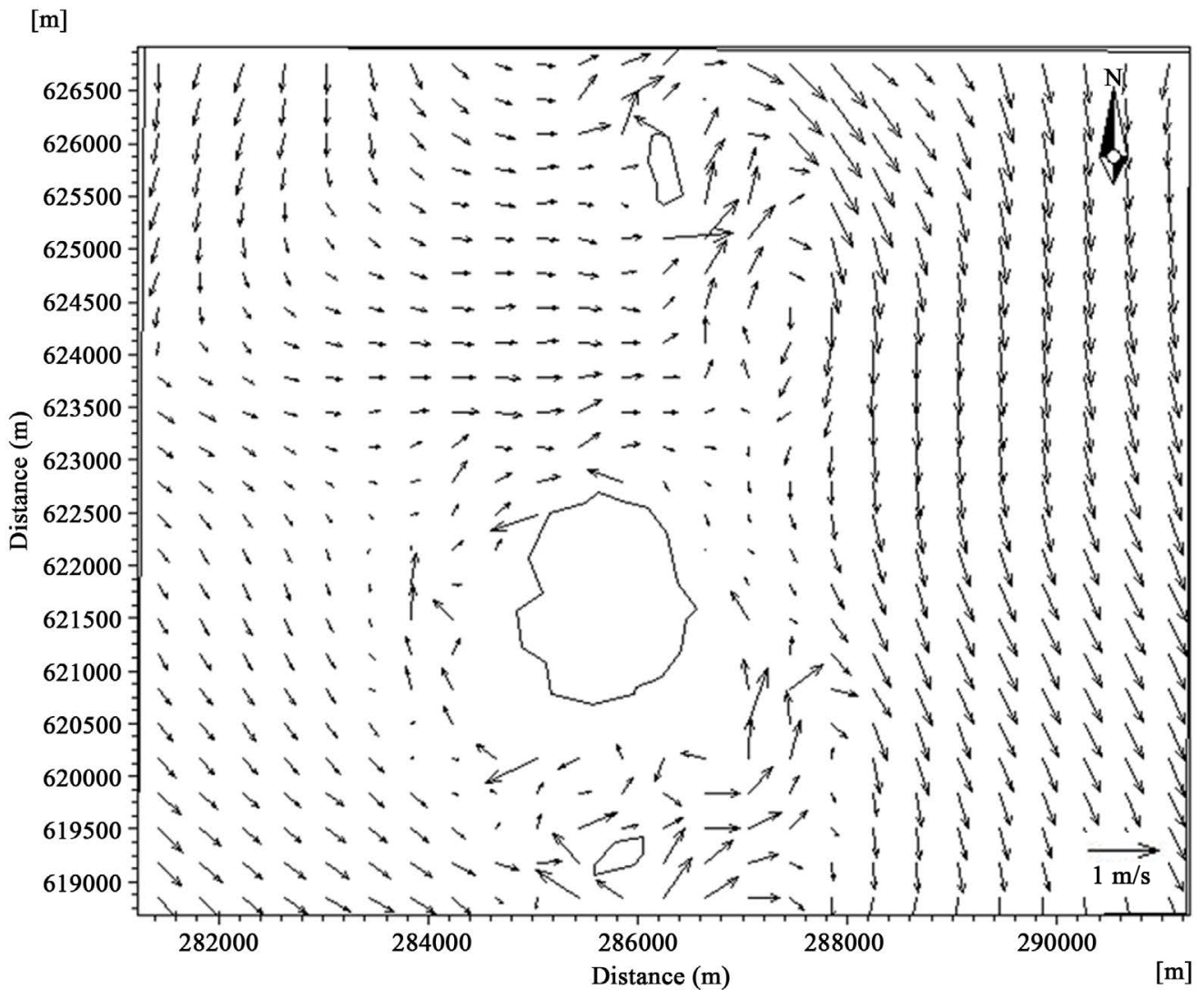

Figure 14. Same as Figure 13 but for Experiment 3. 


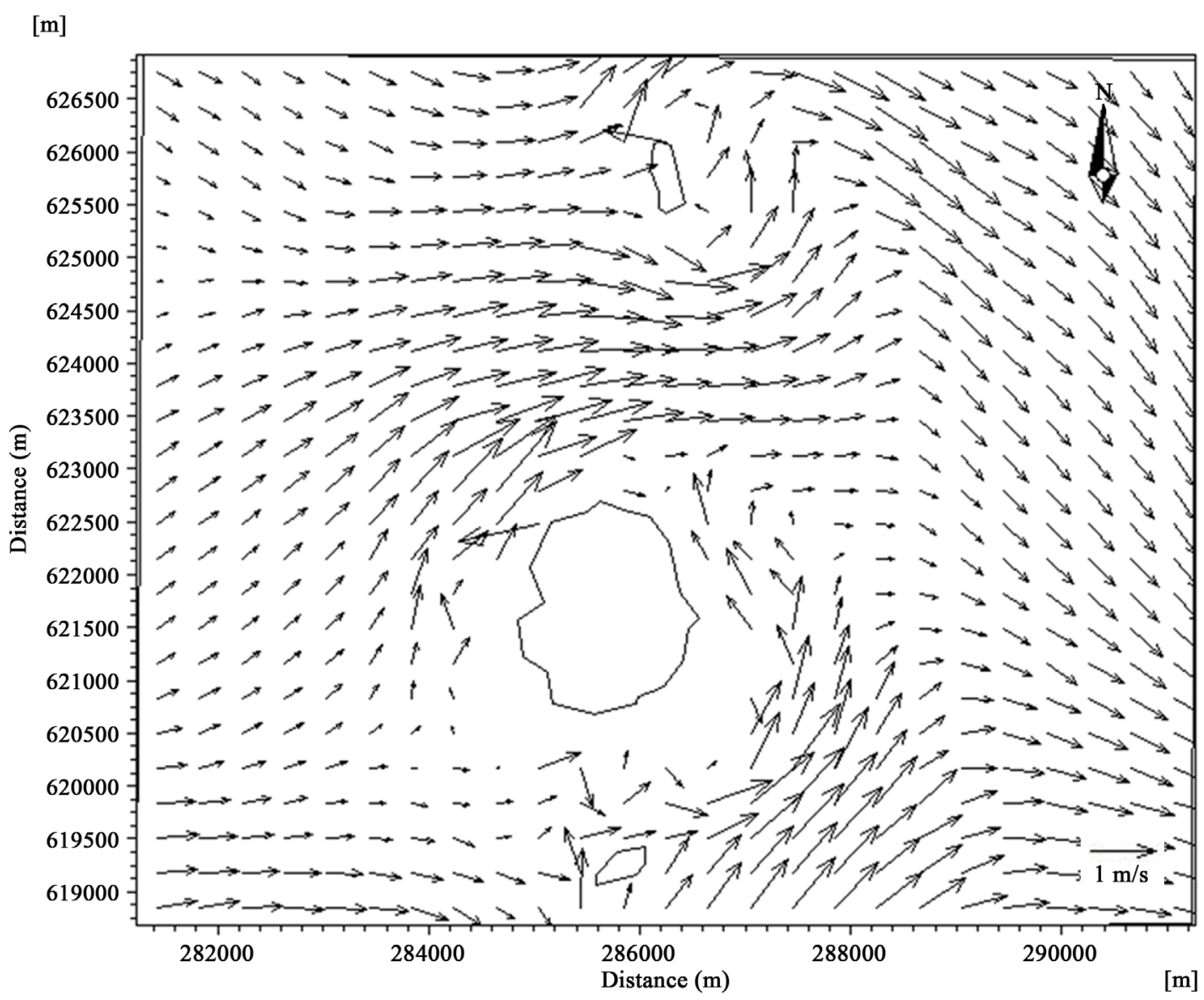

Figure 15. Same as Figure 13 but for Experiment 5.

speed as compared to southern part. The maximum current speed in this model was $0.22 \mathrm{~m} / \mathrm{s}$ and minimum current speed was $0.06 \mathrm{~m} / \mathrm{s}$.

From E3, E4 and E5 there was a clear current seen coming up from south to the north and deflection to the west in the middle of it. This deflection was due to the incoming current from the narrow strait at the northern part of Bidong Island which was facing towards the open sea zone and other side zone. However in E5 this incoming current from this narrow strait was not clearly seen. This gave an idea that this narrow strait worked with the tidal effect and when the wind forcing involved southwestern wind played important key in current circulation around this island.

The NE monsoon was generally much greater than in SW monsoon, because it had strong northeasterly wind in the SCS opening. As the Bidong Island's location was facing directly to open sea, it received large wind impact from the open sea.

In E6 the maximum current speed was $0.08 \mathrm{~m} / \mathrm{s}$ and minimum current speed was $0.01 \mathrm{~m} / \mathrm{s}$. However, the mean of current speed in E6 was the lowest compared to other experiments. This showed that tidal effect gave less influence in E6 condition. The mean current speed in this experiment was $0.02 \mathrm{~m} / \mathrm{s}$.

On the other hand, in E7 (see Figure 16) the maximum current speed was $0.26 \mathrm{~m} / \mathrm{s}$ and minimum current speed was $0.07 \mathrm{~m} / \mathrm{s}$. The mean value current speed was $0.17 \mathrm{~m} / \mathrm{s}$ which was the highest mean compared to other experiments. There also presented of island wake at the west part of Bidong Island in E7. This suggested due to strong wind from open sea of SCS and at the end of island in opposite direction of wind direction the island wake developed. This meant that northeastern wind forcing in December played an important key in current circulation during this period.

Based on the seven experiments held, the statistical values were extracted and show in Table 5. From this table, during December strong wind was recorded, as opposed to August. It also showed that wind forcing gave 


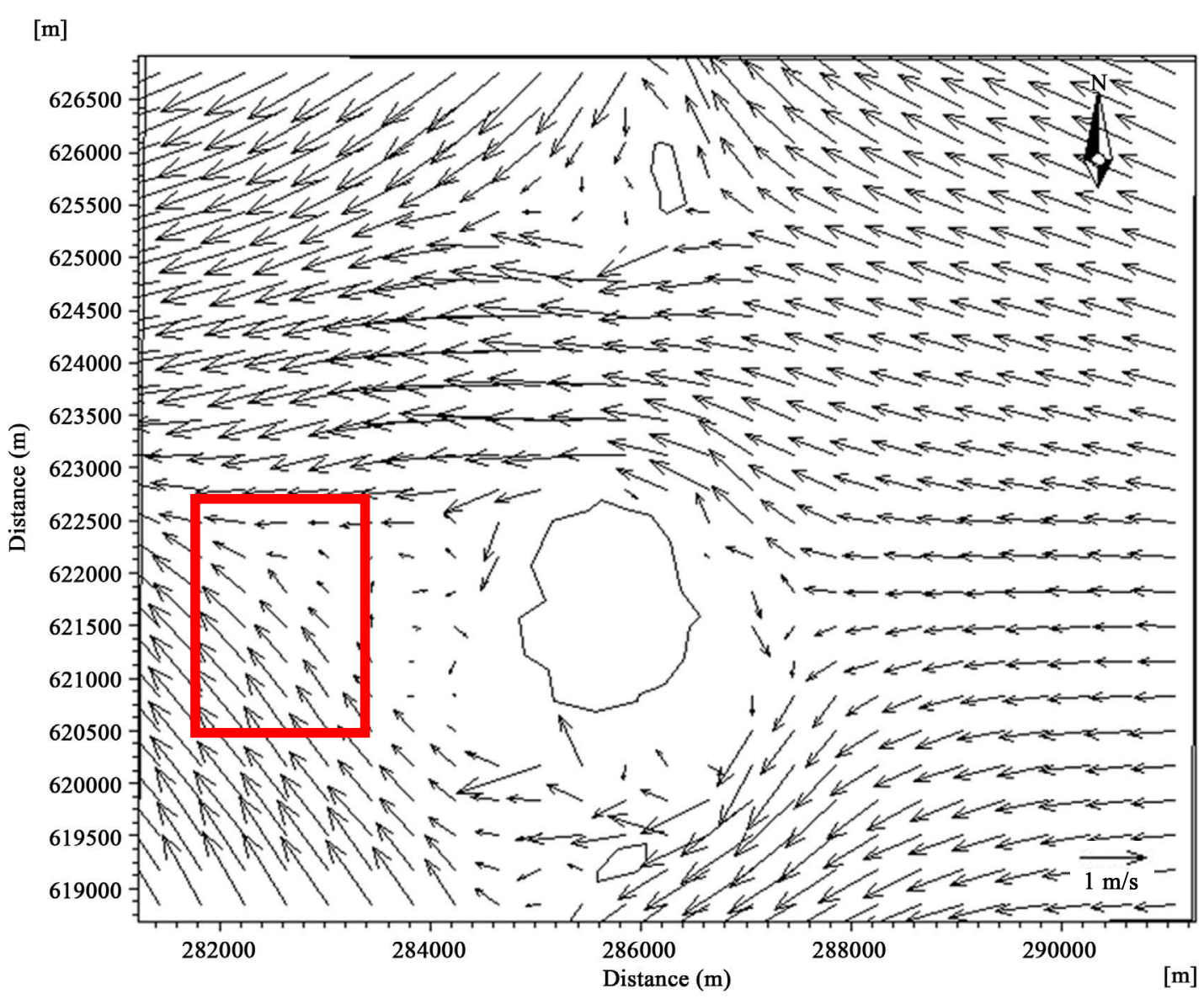

Figure 16. Same as Figure 13 but for Experiment 7.

Table 5. Statistical analysis residual current.

\begin{tabular}{cccc}
\hline & Max value & Min value & Mean \\
\hline E1 & 0.146 & 0.037 & 0.106 \\
E2 & 0.147 & 0.046 & 0.106 \\
E3 & 0.148 & 0.045 & 0.107 \\
E4 & 0.156 & 0.039 & 0.110 \\
E5 & 0.224 & 0.057 & 0.147 \\
E6 & 0.075 & 0.009 & 0.021 \\
E7 & 0.255 & 0.072 & 0.171 \\
\hline
\end{tabular}

larger impact to current circulation as compared to tidal effect. Current circulation becomes stronger during NE monsoon in December since the wind forcing is greater.

The results suggested during SW monsoon there were two dominant factors in current circulation which were wind forcing and tidal effect and the difference between these two factors only two decimal places. However, during NE monsoon the tidal effect was not considered as a strong impact to current circulation as during SW monsoon. Combination between tidal and wind forcing gave strong current speed in E7.

\section{Conclusions}

The numerical model analysed current circulation in the studied region based on selected forcing input. Mike Flow Model FM was used as a tool in methodology of this study. Model validation performed reasonable match 
between modelled and measured current speed. The key finding of this study was wind forcing and followed by tidal force are dominant controlling factors in this study region current circulation system.

This study concluded that wind and tides were major controlling factors in Bidong Island accordingly. Combination of these two factors created maximum current speed in simulated model. Thus, this implied that, in the future numerical study of circulation in this study region, the insertion of the tidal effect and wind forcing would be important.

Current direction flow according to direction of wind and current speed strengthen by wind speed. Throughout the discussion in previous studies, it suggested a monsoon characteristic in SW monsoon had a consistent current strength as compared to NE monsoon. Additionally, during NE monsoon the island wake of Bidong Island was appeared in modelling result and this event should be confirmed with field observation for future work from this study.

\section{Acknowledgements}

This research is supported by E-Science Funding (Grant VOT-52055) through their sponsorship of the MOSTI. Authors acknowledge the support of the Institute of Oceanography and Environment for field work and facilities for data analysis.

\section{References}

[1] Ho, C., Zheng, Q., Soong, Y.S., Kuo, N. and Hu, J. (2000) Seasonal Variability of Sea Surface Height in the South China Sea Observed with TOPEX/Poseidon Altimeter Data. Journal of Geophysical Research, 105. http://dx.doi.org/10.1029/2000jc900001

[2] Wolanski, E., Imberger, J. and Heron, L. (1984) Island Wakes in Shallow Coastal Waters. Journal of Geophysical Research, 89, 553-569. http://dx.doi.org/10.1029/jc089ic06p10553

[3] Planquette, H., Statham, P.J., Fones, G.R., Charette, M.A., Moore, C.M., Salter, I., et al. (2007) Dissolved Iron in the Vicinity of the Crozet Islands, Southern Ocean. Deep Sea Research Part II: Topical Studies in Oceanography, 54, 1999-2019. http://doi.org/10.1016/j.dsr2.2007.06.019

[4] Zwolicki, A., Zmudczyńska-Skarbek, K.M., Iliszko, L. and Stempniewicz, L. (2012) Guano Deposition and Nutrient Enrichment in the Vicinity of Planktivorous and Piscivorous Seabird Colonies in Spitsbergen. Polar Biology, 36, 363372. http://doi.org/10.1007/s00300-012-1265-5

[5] McCarthy, D., Pearce, D., Patching, J. and Fleming, G. (2013) Contrasting Responses to Nutrient Enrichment of Prokaryotic Communities Collected from Deep Sea Sites in the Southern Ocean. Biology, 2, 1165-1188. http://doi.org/10.3390/biology2031165

[6] Tangang, F.T., Mohd Yusof, M.S. and Juneng, L. (2007) Current Circulation Pattern in Waters around Pulau Tinggi, Johor. Sains Malaysiana, 36, 165-173.

[7] Su, Y. and Weng, X. (1994) Water Masses in China Seas. Oceanology of China Seas, 1, 3-26.

[8] Zheng, Q., Susanto, R.D., Ho, C.-R., Song, Y.T. and Xu, Q. (2007) Statistical and Dynamical Analyses of Generation Mechanisms of Solitary Internal Waves in the Northern South China Sea. Journal of Geophysical Research: Oceans, 112, C03021. http://dx.doi.org/10.1029/2006JC003551

[9] Marghany, M. and Hashim, M. (2010) MODIS Satellite Data for Modeling Chlorophyll—A Concentrations in Malaysian Coastal Waters. International Journal of the Physical Science, 5, 1489-1495.

[10] Akhir, M.F. (2012) Surface Circulation and Temperature Distribution of Southern South China Sea from Global Ocean Model (OCCAM ). Sains Malaysiana, 41, 701-714.

[11] DHI (2011) Mike 21 and Mike 3 Flow Model Scientific Documentation. Denmark.

[12] DHI (2012) MIKE 21 FLOW MODEL FM. Denmark.

[13] Batchelor, G. (2000) An Introduction to Fluid Dynamics. Cambridge University Press, Cambridge. http://dx.doi.org/10.1017/CBO9780511800955

[14] Tomczak, M. (1988) Island Wakes in Deep and Shallow Water. Journal of Geophysical Research, 93, 5153-5154.

[15] Shankar, D., Vinayachandran, P.N., Unnikrishnan, A.S. and Shetye, S.R. (2001) The Monsoon Currents in The North Indian Ocean. Progress in Oceanography, 52, 63-120.

[16] Goyal, R. and Rathod, P. (2011) Hydrodynamic Modelling for Salinity of Singapore Strait and Johor Strait Using MIKE 3 FM. Proceedings of the International Conference on Environmental Science and Development, 4, 295-300.

[17] Bourgoyne, M. (2010) Hydrodynamic Modeling of San Elijo Lagoon, California. Louisiana State University, Baton 
Rouge.

[18] Chu, P.C., Edmons, N.L. and Fan, C. (1999) Dynamical Mechanisms for the South China Sea Seasonal Circulation and Thermohaline Variabilities. Journal of Physical Oceanography, 29, 2971-2989. http://dx.doi.org/10.1175/1520-0485(1999)029<2971:DMFTSC >2.0.CO;2

[19] Buranapratheprat, A., Yanagi, T. and Matsumura, S. (2008) Seasonal Variation in Water Column Conditions in the Upper Gulf of Thailand. Continental Shelf Research, 28, 2509-2522. http://dx.doi.org/10.1016/j.csr.2008.07.006

[20] Liu, Z., Yang, H. and Liu, Q. (2001) Regional Dynamics of Seasonal Variability in the South China Sea. Journal of Physical Oceanography, 31, 272-284. http://dx.doi.org/10.1175/1520-0485(2001)031<0272:RDOSVI>2.0.CO;2

[21] Liu, Y., MacCready, P., Hickey, B.M., Dever, E.P., Kosro, P.M. and Banas, N.S. (2009) Evaluation of a Coastal Ocean Circulation Model for the Columbia River Plume in Summer 2004. Journal of Geophysical Research, 114. http://dx.doi.org/10.1029/2008JC004929

[22] Chai, T. and Draxler, R.R. (2014) Root Mean Square Error (RMSE) or Mean Absolute Error (MAE)?-Arguments against Avoiding RMSE in the Literature. Geoscientific Model Development, 7, 1247-1250. http://dx.doi.org/10.5194/gmd-7-1247-2014

[23] Camerlengo, A. and Demmler, M.I. (1997) Wind-Driven Circulation of Peninsular Malaysia’s Eastern Continental Shelf. Scientia Marina, 61, 203-211.

[24] He, R., Liu, Y. and Weisberg, R.H. (2009) Coastal Ocean Wind Fields Gauged against the Performance of an Ocean Circulation Model. Geophysical Research Letters, 31, Article ID: LI4303.

[25] How, W.S., Muhamad, H., Tangang, F.T. and Juneng, L. (2012) Projection of Storm Surge Climate Extreme over Sunda Shelf Based on IPCC SRES A2 Scenario. Sains Malaysiana, 41, 1411-1422.

[26] Zhang, H., Sannasiraj, S.A. and Chan, E.S. (2009) Wind Wave Effects on Hydrodynamic Modeling of Ocean Circulation in the South China Sea. The Open Civil Engineering Journal, 3, 48-61. http://dx.doi.org/10.2174/1874149500903010048

[27] Wannasingha, U., Webb, D.J., De Cuevas, B.A. and Coward, A.C. (2000) On the Indonesian Throughflow in the OCCAM Model. Ocean Science Discussions, 2.

[28] Hu, J., Kawamura, H., Hong, H. and Qi, Y. (2000) A Review on the Currents in the South China Sea : Seasonal Circulation, South China Sea Warm Current and Kuroshio Intrusion. Journal of Oceanography, 56, 607-624. http://dx.doi.org/10.1023/A:1011117531252

[29] Cai, S., Su, J., Gan, Z. and Liu, Q. (2002) The Numerical Study of the South China Sea Upper Circulation Characteristics and Its Dynamic Mechanism, in Winter. Continental Shelf Research, 22, 2247-2264. http://dx.doi.org/10.1016/S0278-4343(02)00073-0

[30] Akhir, M.F., Sinha, P.C. and Hussain, M.L. (2011) Seasonal Variation of South China Sea Physical Characteristics off the East Coast of Peninsular Malaysia from 2002-2010 Datasets. International Journal of Environmnet Sciences, 2, 569-575. 